\title{
KOMPOZIT ALKATRÉSZ NUMERIKUS ELEMZÉSE MIKROMECHANIKAI JELLEMZŐK FIGYELEMBEVÉTELÉVEL
}

\author{
Beleznai Róbert \\ adjunktus, Miskolci Egyetem, Energetikai és Vegyipari Gépészeti Intézet, Vegyipari Gépészeti Intézeti Tanszék \\ 3515 Miskolc, Miskolc-Egyetemváros, e-mail:vegybl@uni-miskolc.hu
}

Spisák Bernadett

PhD hallgató, Miskolci Egyetem, Energetikai és Vegyipari Gépészeti Intézet, Vegyipari Gépészeti Intézeti Tanszék

3515 Miskolc, Miskolc-Egyetemváros, e-mail vegysb@uni-miskolc.hu

\section{Siménfalvi Zoltán}

egyetemi docens, dékán, intézeti tanszékvezetö, Miskolci Egyetem, Energetikai és Vegyipari Gépészeti Intézet, Vegyipari Gépészeti Intézeti Tanszék 3515 Miskolc, Miskolc-Egyetemváros, e-mail: simenfalvi@uni-miskolc.hu

\begin{abstract}
Absztrakt
Az elemzés célja egyrészt egy kompozit anyagból készült alkatrész numerikus elemzése anyagának mikromechanikai jellemzöi figyelembevételével, másrészt ehhez kapcsolódóan annak vizsgálata, hogy az eredetileg fémböl készült alkatrész kiváltható-e kompozit polimer anyaggal az alkatrész súlyának csökkentése mellett a funkcionális és szilárdsági jellemzők megtartásával. A kompozit alkatrész gyártástechnológiájából eredö anizotrópiájának meghatározásához elvégeztük az alkatrész fröccsöntés technológiai szimulációját, majd a szimulációs eredmények felhasználásával végeselem analizis segitségével meghatároztuk az alkatrész statikus mechanikai terhelés esetén fellépö igénybevételeit.
\end{abstract}

Kulcsszavak: kompozit, mikromechanikai jellemzök, technológiai szimuláció, végeselem módszer

\begin{abstract}
The aims of the study are to perform numerical analysis of a component made of a composite material taking into account its micromechanical characteristics and to investigate whether the original metal component can be replaced by a composite polymer material while reducing the weight of the part as well as retaining the functional and strength characteristics. To determine the anisotropy of the composite part resulting from the manufacturing technology, injection moulding simulation of the part is performed and then mechanical response of the composite part in case of static load is determined using finite element method considering the simulation results.
\end{abstract}

Keywords: composite, micromechanical properties, technological simulation, finite element method

\section{Bevezetés}

Napjainkban jelentős mennyiségü kompozitot használnak fel az autóiparban hibrid és elektromos jármủveknél, ezzel csökkentve az autó súlyát. Természetes szálerősítésủ kompozitokból készülnek a családi autók belső díszítőelemei és tartályai, kompozitból vannak a nagyméretű panelek az autóbuszokon és közepes méretü teherautókon. A nehéz tehergépkocsiknál a teljes fülkét kompozitból készítik és az ütközö elemeknél energiaelnyelésre is alkalmazhatóak. Ezek az elemek fontos szerepet ját- 
szanak a hagyományos anyagok leváltásában, így csökkentve a súlyt, emellett növelve az utasok biztonságát [1]. A könnyü kompozit anyagok lehetőséget adnak az üzemanyag hatékonyságának növelésére és a környezetbe kibocsájtott káros anyag mennyiség csökkentésére is.

A tanulmány célja a súlycsökkentési lehetőség elemzése egy eredetileg fémből készült személygépjármű szelepfedél alkatrésze esetén. Ez egy többlépcsős folyamat: első lépésként a geometriát kell módosítani a fröccsöntés technológiai szempontoknak megfelelően (oldalferdeség, egyenletes falvastagság stb.), hogy a darab minden része az elvárt sürüségi és szilárdsági jellemzőkkel rendelkezzen; ezután következik a fröccsöntési folyamat szimulációja a mikromechanikai jellemzők meghatározásához. Ezt input adatként felhasználva következik az alkatrész igénybevételeinek meghatározása végeselem módszerrel. Végül az elemzések értékelése, hogy a kívánt súlycsökkentés elérhetö-e funkcionális és szilárdsági jellemzők megtartása mellett.
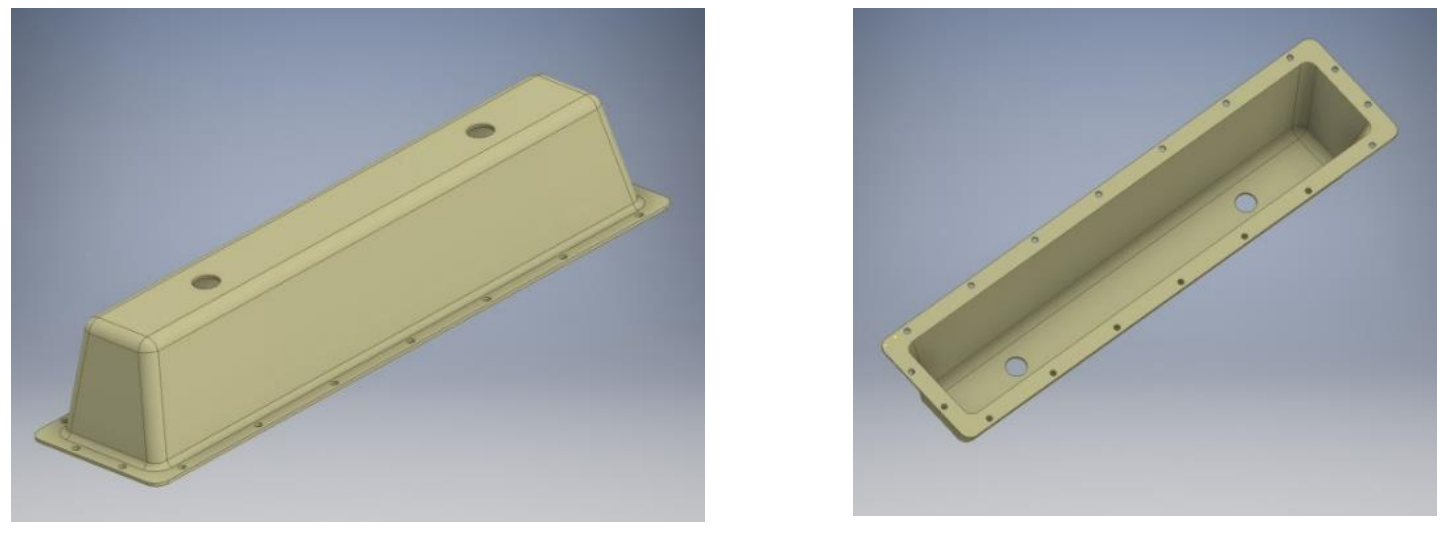

1. ábra. A szelepfedél

\section{Kompozit anyag}

A kompozitok fémekkel szembeni legnagyobb előnye, hogy a szállal erősített hőre lágyuló müanyagok szilárdság/tömeg és merevség/tömeg hányadosa (a fajlagos szilárdság és merevség) kedvezőbb. További előnyük a jobb vegyszerállóság és korrózióállóság és színezhetőség. A formadás a hagyományos mủanyag-feldolgozási módszerekkel (elsősorban fröccsöntéssel) nagy rugalmasságot jelent a termék tervezésekor [2]. Anyagi szálak vagy részecskék egy mátrixba történő beágyazódásával olyan tulajdonságok érhetőek el, amelyek egyik kiinduló anyag esetén sincsenek jelen. Megfelelő merevség és szilárdság biztosítható lényegesen alacsonyabb sürüség mellett, mely a termék súlyának csökkentését eredményezi.

A kompozitokban a teherviselő komponens az erősítő anyag, a mátrix feladata pedig, hogy védje az erősítő anyagot, közvetítse és eloszlassa a terhelést az erősítő elemek között. A kompozit szerkezet létrehozásának alapvető kritériuma, hogy a komponensek között (azok határfelületén) a tapadás megfelelő szilárdságú legyen. A jó tapadás biztosítható az erősítőanyagok előzetes felületkezelésével, vagy megfelelő tapadásközvetítő anyagok (adalékok) hozzáadásával. A múanyagok erősítésére többnyire különböző szálakat (rövid, hosszú és folyamatos szál) alkalmaznak. A legáltalánosabban alkalmazott erősítőszálak az üvegszál, szénszál, aramid szál és az ultra nagy molekulatömegü polietilén szál [3]. A kompozit szilárdsága és merevsége közel megegyezik az erősítő szál anyagáéval, de a mátrix anyag is befolyással van az egyes tulajdonságokra. A kompozit mechanikai viselkedését az erősítő anyag és a 
mátrix közötti szinergia is befolyásolja, ezenkívül hatással van még az erősítő anyag alakja is. A kompozit tulajdonságait meghatározó tényezők [4]:

- A szál-mátrix határfelületi adhézió

- A mátrix és az erősítő elem mechanikai tulajdonságai

- A száltartalom, a szálak hossza és átmérője, irányítottsága a mátrixban (orientáció)

- A gyártási technológia

A fröccsönthető rövid szálerösítésű, hőre lágyuló polimerek képviselik azon típusú kompozitokat, ahol csak az erősítő szálak koncentrációját szabályozzák, és nem a pontos méretüket vagy orientációjukat [3]Hiba! A hivatkozási forrás nem található.

A kompozit szelepfedélhez a DuPont által kifejlesztett PA 66 (Zytel® 70G35HSLRA4 BK267) anyagot választottuk, mely 35\%-ban tartalmaz üvegszál erősítést, illetve a mátrixa hidrolízis álló poliamid 66-ból áll. A kompozit ellenálló a forró olajokkal és zsírokkal szemben. A poliamidokat már régóta használják műszaki alkalmazásokra, mivel kiváló a szakítószilárdsága, a kémiai és a kopásállósága, magas olvadásponttal rendelkezik és a kifáradással szemben is nagy az ellenálló képessége.

\section{Fröccsöntés szimuláció}

A fémalkatrész kiváltása kompozit anyagra az alkatrész geometriájának bizonyos szintü áttervezését igényli a kompozit anyagának megfelelően. Ahhoz, hogy a kompozit alkatrész funkcionálisan és minden egyéb szempontból egyenértékü legyen a kiváltandó fémalkatrésszel általában iterációs folyamatra (2. ábra) van szükség. Ennek során először elvégezzük a kompozit alkatrész technológiai szimulációját (jelen esetben fröccsöntés), melynek eredményeit (szálorientáció, összecsapási vonalak, maradó feszültség) figyelembe véve elkészítjük a végeselem modellt, ahol az alkatrészre ható terhelések és megfogások alapján meghatározzuk az abban ébredő igénybevételeket.

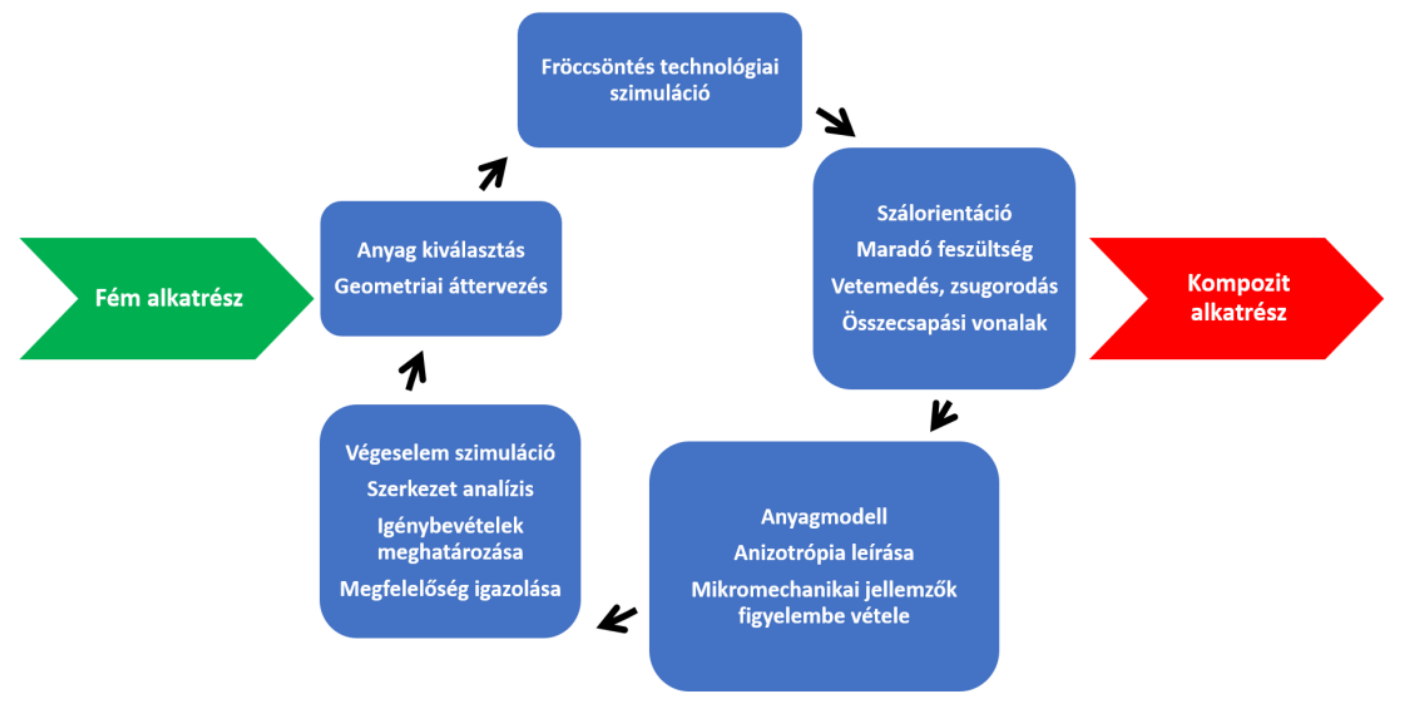

\section{2. ábra. Komplex kompozit alkatrész elemzésének folyamata}

A kompozit alkatrész fémalkatrésszel történő összehasonlítás eredménye alapján módosítjuk a modell geometriáját, adott esetben a kompozit összetételét, lokális struktúráját, majd újra elvégezzük a fent bemutatott elemzési folyamatot. Ezt addig ismételjük, amíg a megfelelő tulajdonságokkal rendel- 
kező terméket nem kapjuk. Az iterációhoz két szimulációs szoftver együttes alkalmazására van szükség: az egyik a gyártástechnológiai modellező szoftver, amellyel a gyártás folyamatának és a gyártás végén adódó termék sajátosságai határozhatók meg, a másik egy általános célú végeselem szoftver, mellyel a szerkezet terhelésekre adott válaszát tudjuk meghatározni a gyártásból kapott lokális információk figyelembevételével. Egy teljes fröccsöntési szimuláció tartalmazza a kitöltés, az utónyomás, a lehütés folyamatokat és ezek mellett a gyártás során keletkező vetemedésről is képet kapunk. Eredményül a zsugorodást, vetemedés mértékét, a hegedési vonalak, légbuborékok helyét, az ömledékfrontnál lévő hőmérsékletet és a beömlő csatornáknál lévő hőmérsékletet kapjuk meg. A szerszám kitöltéséhez szükséges idő megközelítőleg 2 másodperc (3. ábra). Az elemzés során nagy figyelmet kell szentelni az összecsapási vonalak elhelyezkedésére, mivel ezek hatására az adott helyeken az anyag mechanikai tulajdonságai nagymértékben lecsökkenhetnek. Ha az eltérő olvadási frontok találkozás előtt lehülnek, akkor nem képesek megfelelően egymáshoz csatlakozni, szerkezetintegritási problémát okozva az alkatrészben. Ennek elkerülésére megoldás lehet a gátak helyének újra pozícionálása, a darab vastagságának a megváltoztatása, a kitöltő rendszer optimalizálása, valamint a polimer és a forma hőmérsékletének a növelése. A szimuláció alapján a keletkező összecsapási vonalak hegedési szögének minimális értéke $70^{\circ}$, amely megfelelö, mivel a minimális szögértékek nagyobbak, mint $45^{\circ}$, így nincs szükség a technológiai paraméterek megváltoztatására. A hegedési szög mellett a az ömledék frontok hömérséklete is befolyásolja az összecsapási vonal minőségét, azonban ennek maximális különbsége $4{ }^{\circ} \mathrm{C}$, ami nem jelentős. A vetemedés analízisből (4. ábra) származó maximális elmozdulás értéke $3,46 \mathrm{~mm}$, amely szintén elfogadható mértékü.

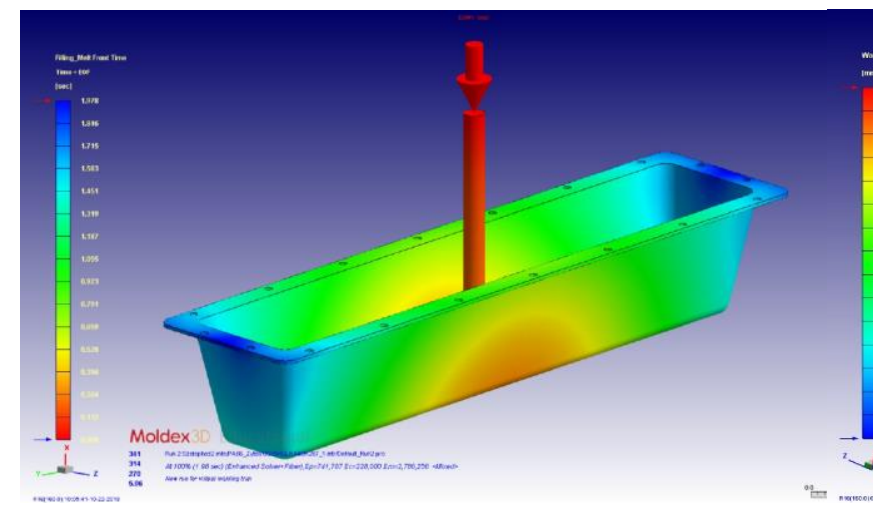

3. ábra. Kitöltési idö

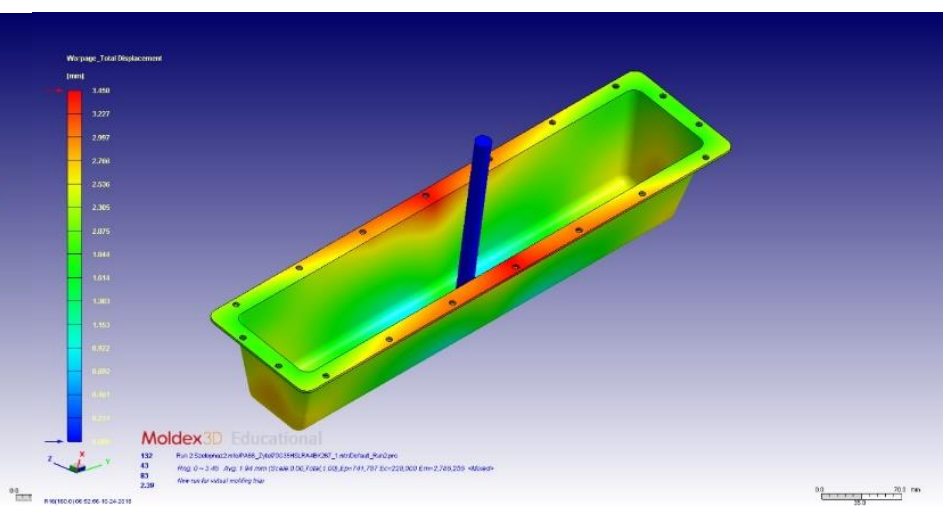

4. ábra. A darab vetemedése

\section{Végeselem analízis mikromechanikai jellemzők figyelembevételével}

A fröccsöntés szimuláció eredményeinek felhasználásával végeselem szimulációt végeztünk a vizsgált alkatrész megfelelőségének igazolására. A mikromechanikai jellemzők végeselem analízisbe való átvitele az eredmények homogenizálását követeli meg. Az elemzés során különböző szintủ homogenizációra van lehetőség, melytől függően többé, vagy kevésbé egyszerüsödik (szálorientációtól függően) a feladat, illetve változik a számítás eredményének pontossága. Az anizotróp tulajdonságok ismerete elem szinten áll rendelkezésre, azaz, ahány elemet tartalmaz a fröccsöntés szimuláció, annyi különböző anizotrópiával rendelkező anyagi viselkedéssel kell számolnunk. Ez pontosabbá teszi a számítási eredményeket, azonban a számítási időt és a modell komplexitását megnöveli. Homogenizációs módszerek segítségével csökkenthető az anizotróp anyagok száma. 
A homogenizácó alapvető feladata az, hogy olyan egyenértékű homogén anyagot találjunk, amely rendelkezik ugyanazzal az effektív makro merevséggel, mint a valóságos, több komponensü heterogén kompozit ugyanazon peremfeltételek mellett. Tehát, makroszinten minden anyagi pontra egy reprezentatív térfogati elem (RVE) közepeként tekinthetünk, amelynek elég nagynak kell lennie ahhoz, hogy képviselni tudja a heterogén mikroszerkezetet, és elég kicsinek a vizsgált testhez képest. Ennek megoldására létezik többfajta módszer: aszimptotikus vagy matematikai homogenizálási elmélet, cellák módszere, szubcellák és transzformációs mező elemzése, közvetlen végeselem analízis, mean-field homogenizáció (MFH). Ez utóbbi fél-analitikus modelleken alapszik és fontos elönye a könnyü és gyors használat, kisebb memória igény. Hátránya, hogy csak a feszültségek és deformációk térfogat átlagára ad közelítést makroszinten és az egyes fázisokban. Különböző MFH modellek léteznek, melyek közül a Mori-Tanaka modellt (1973) alkalmaztuk. Itt minden beágyazott elem az RVE-n belül úgy viselkedik, mintha el lenne különítve a valós mátrixban, amely végtelen nagyságú és az átlag mátrixnyúlásnak megfelelően van terhelve Hiba! A hivatkozási forrás nem található.. Elméletileg a beágyazott elemek térfogataránya nem lehet nagyobb egy adott értéknél (kevesebb, mint 25\%), de a gyakorlatban jó közelítést ad ezen a tartományon kívül is.

A fröccsöntés szimulációs eredmények exportálásakor a kompozit anyagok esetében a szálak orientációja miatt az alkatrész különböző részein a mechanikai tulajdonságok eltérőek lesznek. Egy elemen belül rengeteg szál található, a Mori-Tanaka módszer ezen irányok figyelembevételével készíti el az adott elemre vonatkozó anyagi paramétereket, anizotróp anyagmodellt alkalmazva. Minden egyes elem esetén ezek a paraméterek eltérőek, hiszen a bennük lévő szálak mennyisége és orientációja is eltérö, ezért a modell annyi anyagi paramétert hoz létre ahány elemből áll a modell. Azonban ez túl hosszú számítási időt vesz igénybe a végeselemes szimuláció során. A homogenizálás segítségével egy adott tartományon belül a hasonló szálorientációval rendelkező elemeknél azonos anizotróp anyagi tulajdonság állítható be, ezzel csökkentve a számítási időt (1. táblázat).

1. táblázat. Anizotróp anyagok száma a homogenizálás szintjétöl függően

\begin{tabular}{|c|c|c|c|c|c|c|c|}
\hline Háló & Elemszám & $\begin{array}{c}\text { Maximális } \\
\text { redukálás }\end{array}$ & $\begin{array}{c}\text { Magas } \\
\text { szintú re- } \\
\text { dukálás }\end{array}$ & $\begin{array}{c}\text { Közepes } \\
\text { szintú re- } \\
\text { dukálás }\end{array}$ & $\begin{array}{c}\text { Alacsony } \\
\text { szintú } \\
\text { redukálás }\end{array}$ & $\begin{array}{c}\text { Minimális } \\
\text { szintú } \\
\text { redukálás }\end{array}$ & $\begin{array}{c}\text { Redukálás } \\
\text { nélkül }\end{array}$ \\
\hline 1 & 66627 & 25 & 3195 & 10443 & 18267 & 23225 & 66627 \\
\hline
\end{tabular}

Figyelembe kell venni, hogy két egymás mellett elhelyezkedő elem nem feltétlenül rendelkezik azonos mennyiségű szállal és orientációval, ezért lehetséges, hogy a magasabb szintủ redukálás esetén egy teljesen más területen lévő elem anyagi paramétereivel fog rendelkezni.

\section{Eredmények}

A szelepfedél müködése során $130 \mathrm{kPa}$ belső nyomással van terhelve. Az alkatrész a peremén kialakított furatokon keresztül csavarkötés segítségével kerül rögzítésre a motorblokkhoz, így ezen furatok kerületén megfogás peremfeltételt definiáltunk. Az eredmények közül az elmozdulás mező (5. ábra) x irányú komponensének (ez az alkatrész peremére merőleges komponens) eloszlása van a legnagyobb befolyással a tömítettségre vonatkozóan, illetve a szelepfedélben ébredő redukált feszültség nagyságát kell ellenőrizni (2. táblázat). Az elmozdulás értékre gyakorlatilag a magas szintü homogenizációtól a redukálás nélküli változatig ugyanazt az eredményt kapjuk, jelentősebb eltérés csak a maximális szintü homogenizáció esetén tapasztalható. A feszültség értékekben magasabb szintü homogenizáció esetén nagyobb, de 15\%-os tartományon belül ingadozás tapasztalható. 
2. táblázat. A homogenziáció szintjének függvényében az elmozdulás és a redukált feszültség változása

\begin{tabular}{|c|c|c|c|c|c|c|}
\hline Redukálás szintje & Maximális & Magas & Közepes & Alacsony & Minimális & $\begin{array}{c}\text { Redukálás } \\
\text { nélkül }\end{array}$ \\
\hline Anizotróp anyagok száma & 25 & 3195 & 10443 & 18267 & 23225 & 66627 \\
\hline X irányú elmozdulás, mm & 0,161 & 0,144 & 0,146 & 0,146 & 0,146 & 0,146 \\
\hline Mises redukált feszültség, MPa & 44,4 & 37,7 & 42,7 & 42,9 & 37,5 & 37,0 \\
\hline
\end{tabular}

A 6. ábra a kompozit anyag feszültség-nyúlás görbéjét mutatja. A piros színnel jelölt görbe esetén a terhelés iránya megegyezik a szál irányával, a zöld színnel jelölt görbenél pedig a terhelés iránya merőleges a szál irányára. Leolvasható, hogy rugalmassági határ maximális értéke $80 \mathrm{MPa}$, minimális értéke pedig $40 \mathrm{MPa}$ környékén található. Ebből azt a következtetést lehet levonni, hogy a szelepfedél üzem közben a felfogatási pontoknál esetleg a rugalmassági határ fölötti igénybevételnek is ki lehet téve, amennyiben a közepes vagy az alacsony szintü homogenizációt vesszük alapul, azonban minimális szintü, vagy redukálás nélküli esetben a feszültség érték a rugalmassági határ alatt marad. Ezen részek megerösítésére inzertek alkalmazását javasoljuk, így a terhelést az inzertek fogják nagyobb részt felvenni, tehermentesítve a kompozit alkatrész peremét.

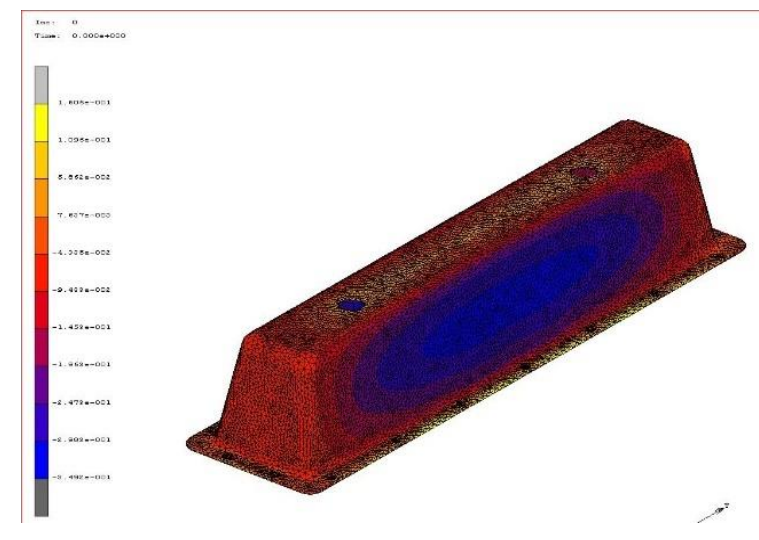

5. ábra. A szelepfedél peremére meröleges irányú elmozdulás, max. 0,161 mm

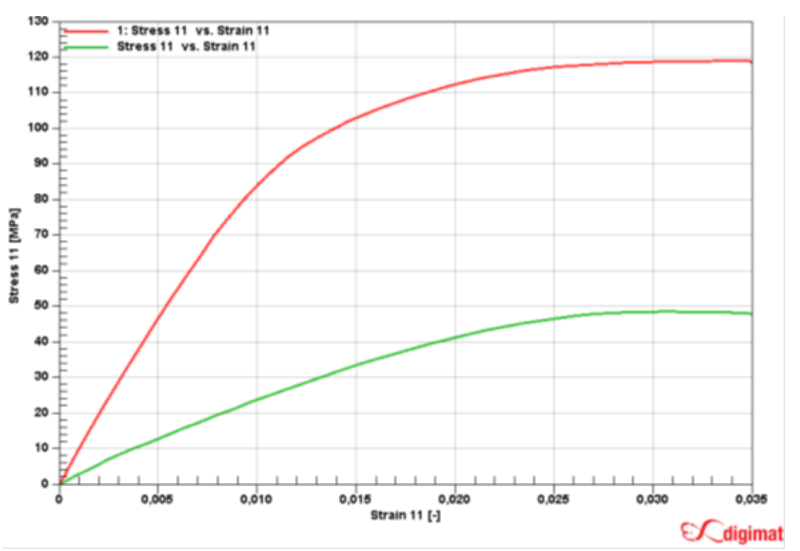

6. ábra. Feszültség nyúlás görbe

\section{6. Összefoglalás}

Egy rövid szállal erősített kompozit alkatrész technológiai és szilárdsági analízisét végeztük el, melynek során részletesen elemeztük a fröccsöntési folyamat szakaszait (kitöltés, utónyomás, hütés és vetemedés). A fröccsöntés analízis segítségével kapott mikromechanikai jellemzők figyelembevételével elvégeztük a szelepfedél végeselem szimulációját statikus terhelés esetére. Az elemzés végeredményeként kapott kompozit szelepfedél szilárdságilag megfelelö és ráadásul több mint 50\%-kal kisebb súlyú, mint a fémből készült eredeti verzió. 


\section{Köszönetnyilvánítás}

A cikkben ismertetett kutató munka az EFOP-3.6.1-16-2016-00011 jelü „Fiatalodó és Megújuló Egyetem - Innovatív Tudásváros - a Miskolci Egyetem intelligens szakosodást szolgáló intézményi fejlesztése" projekt részeként - a Széchenyi 2020 keretében - az Európai Unió támogatásával, az Európai Szociális Alap társfinanszírozásával valósul meg.

\section{Irodalom}

[1] Malnati, P., Forward. In: Vaidya, U.: Composites for automotive, truck and mass transit, DEStech Publ. Inc., Lancaster, Pennsylvania, USA, 2011.

[2] Bánhegyi, Gy.: Szállal erösitett müanyagok, https://docplayer.hu/10305336-Targyszavakszalerosites-erositoszalak-feluletkezeles-tulajdonsagok-wollastonit-poliamid-polipropilen.html

[3] Réti, T., Zsoldos, I.: Válogatott fejezetek az anyagtudományból, MSc leckék, Kompozit lecke, Széchényi István Egyetem, TÁMOP 4.1.2/A-013/05, 2011.

[4] Hargitai, H.: Polimer kompozitok alapanyagai, tulajdonságai, kompozitmechanikai alapok, NGB_AJ050_1, Széchenyi István Egyetem, Anyagismereti és Jármügyártási Tanszék, 2011.

[5] Mori, T., Tanaka, K.: Average stress in the matrix and average elastic energy of materials with misfitting inclusions, Acta Metall, Mater., 21, (1973) pp. 571-574.

https://doi.org/10.1016/0001-6160(73)90064-3 